\title{
Educationalization of Social Problems and the Educationalization of the Modern World
}

Daniel Tröhler ${ }^{1}$

I University of Luxembourg, Esch-sur-Alzette, Luxembourg

Daniel Tröhler

Email: daniel.troehler@uni.lu

Without Abstract

\section{Synonyms}

Educationalisation; Pedagogisation; Pedagogization

\section{Introduction}

The catchword "educationalization," which enjoyed some popularity around 1920, has been used increasingly since the 1980s, first in the German and then in the Belgian and English discussions. Although the uses of and intentions behind the term are far from identical, they all express a perceived intersection between distinct social practices, one of which is education. As a rule, this intersection is interpreted as assigning education the task of coping with perceived social problems. Accordingly, the most popular expression of this mode of thought has been labeled, in an abstracting way, the educationalization of social problems. This entry builds on that but suggests a more comprehensive view, less reactive in character by claiming that since the eighteenth century the construction of modernity, progress, and open future depends on an idea of education that promises to be the engine of modernity by means of (new) and broadly disseminated knowledge and technologies and, at the same time, an instance of moral reassurance empowering the individual exposed to these modern conditions and their moral hazards to act morally or virtuously. Educationalization of the modern world, in this more comprehensive way, is a key concept for understanding and deciphering the grand narratives of modernity and the modern self. 


\section{Educationalization of Social Problems}

Even though the label educationalization of social problems has been popular internationally for less than 10 years (Smeyers and Depaepe 2008), the notion goes back to a German discussion in the 1980s under the label Pädagogisierung sozialer Probleme (see Proske 2001). The matter itself, however, is much older and refers to specific issues of hygiene, economy, delinquency and prisoners, and, later on and very broadly received, children's sexuality, pédagogisation du sexe le l'enfant, or pedagogization of children's sex (Foucault 1978, p. 104).

Beyond these explicit uses of "educationalization" the issue itself is omnipresent. Sunday schools and Bible classes were organized for workers in the first half of the nineteenth century to prevent moral decay in light of a monetary economy; most automobile drivers in the world attend driver education classes and have to pass a test - institutionalized in Germany as early as in 1902 -, and children of all ages have traffic education at school to protect them against the dangers of increased motorized traffic. These more gradual processes of educationalization are supplemented by more tangible events. When, for instance, the United States saw their nation and the Western world at risk after the launch of Sputnik by the Soviet Union in 1957, it educationalized the Cold War by passing the very first national education law, the National Defense Education Act in 1958, expressing the view that "Education is the First Line of Defense" (Rickover 1959). And when, a few years later, the environment had become an affair of public concern, for instance triggered by the book Silent Spring (Carson 1962), endangered nature became educationalized, as expressed, for instance, in the Journal of Environmental Education (1969) and in educational trails teaching walkers about nature. And when again a few years later in the United States the national crises after the Vietnam War, the oil crises in the 1970s, and the near collapse of the automobile industry in the early 1980s led to the perception of A Nation at Risk and the conclusion of an Imperative For Educational Reform, this expressed the educationalization of economy and economic policy. A rising teenage pregnancy rate in the 1960s led to an educationalization of sex through the introduction of sex education in schools, which gained new urgency with the outbreak of HIV/AIDS in the 1980s. Museums were made more attractive by the invention of museum education around 1990. And when immigrant adolescents in the suburbs of Paris and Lyon protested violently in 2005, their behavior was not seen as a reaction to their poor living conditions or poor life chances but as an expression of the wrong education, as France's Prime Minister Dominique de Villepin stated in 2005. Human life is a site of what UNESCO has called "lifelong learning" and propagated since 1962, a phenomenon that was critically noticed (and explicitly labeled "educationalization") as early as in 1929 (Fischer $\underline{1929}$, p. 286).

The expansion of the education system in the 1960s and the 1970s as a Western expression of the educationalization of the Cold War also led to a process self-reassurance of the educational sciences, in which the explicit notion of "educationalization," or Pädagogisierung, started to serve 
as a (self-)analytical tool. In this context the notion of the educationalization of prison inmates has been discussed, profiting of course from the immense discussion of Foucault's account of the Birth of the Prison (Foucault 1977). Additionally, relevant research focused on educationalization phenomena in all kinds of contexts, for instance, in human resources, in marketing, and even in developing city districts, and, of course in developing the Third World (see Proske 2001).

Based on these German disciplinary (self-)reassurances, the Belgian historian of education Marc Depaepe suggested using "educationalization" as a key concept to understand fundamental processes in the history of Western education and dedicated a large part of his research to this idea in the first decade of this century (see Depaepe 2012). Depaepe invited also philosophers of education to participate in this disciplinary self-reflection of education (Depaepe and Smeyers 2008; Smeyers and Depaepe 2008), focusing on the educationalization of social problems. The discussion proved to be fruitful in detecting actual educationalization of phenomena such as health, the family and the child, or even philosophy or educational research. By pointing at the fact that educationalizing social problems continued to be a part of the educational culture even though schools have repeatedly proven that they are an ineffective mechanism for solving these problems, David F. Labaree ( 2008 ) pointed to a larger cultural context than education itself; it is precisely here that the term educationalization of the world, a process starting in the long eighteenth century, gets a distinct meaning with regard to the educationalization of social problems.

\section{The Educationalization of the World in the Long Eighteenth Century I: The Challenge}

Up to the mid-eighteenth century, it was not at all "normal" to interpret perceived problems educationally - that is, to assign the solving of problems to educational practice. What then made this educationalization, this educational turn, possible? This development had very specific requirements that have little to do with education; the increased educational reflexes were reactions to problems that were originally perceived as noneducational. Decisive for the educational turn were changes in the way that people thought about two fundamental things in interpreting their lives: first, how people imagined history and development and second, how they viewed the relation between money and politics. Both of these transformations, which remain important today, occurred around 1700 and replaced older perceptions and core notions that went back to the ancient world. They mark the transformation of the early modern period in history to the modern period. The first of these transitions (history and development) was initiated in France, the second (money and politics) in England. Both together created challenges, "problems," that were addressed in many ways, and the educational way seems to have been deemed the most promising, with effects up to today. 
The transformations in the perception of history and development were initiated in France at the court of the King Louis XIV in Versailles, when the ancients' way of looking at things came under attack in the "quarrel of the Ancients and the Moderns." Whereas up to the end of the seventeenth century, time and thus history had been seen, in analogy to the seasons, as an eternal cycle of events; in the eighteenth century a linear way of thinking ("progress") came to prevail that was oriented towards the future and in which outcomes were open. At first, around 1680, this optimism applied only to progress in the sciences, but soon after, progress was seen also as a social and political program: Humanity would develop progressively towards peace, justice, and bliss, and political conditions that impeded this progress had to be destroyed. This was the justification for the French Revolution of 1789. The most impressive interpretation of this rational thinking on progress is probably that in Outlines of an Historical View of the Progress of the Human Mind by Marquis de Condorcet (1743-1794). According to Condorcet's interpretation, the French Revolution was the gateway to humanity's final great developmental epoch.

The second transformation has to do with the relation of money to politics, which changed towards the end of the seventeenth century at first in England. Up to that time, an ideal had prevailed in Europe according to which dispassionate reason was supposed to guide politics. At the same time, the commercial economy had been considered as something "lower" or "baser," because it was accused of diverting attention and interest away from the common good and of exposing people to the passionate pursuit of profit: In this system of thought, calm, rational governing was seen as good and passion-driven money-making as bad. But around 1700 and up to the present day, this system of thought was lost, not least because the commercial economy had become a social fact and actually very important for politics. This ideological bias - the idea of dispassionate reason as a condition of good politics and the actual importance of the discredited commerce, connected to passions - had to be solved in order to legitimate the systems of political power, which depended more and more on money (for instance, to cover the rising costs of the massive expansion of administration or for the standing armies with their mercenaries).

The two transformations not only found enthusiastic supporters, they also gave rise to existential uncertainty, critique, and debates. The most important reaction to the capitalization of politics in a world that all of a sudden seemed to be driving progressively into an open and unknown future was the revival of a political ideal that in research is called classical republicanism or civic humanism (Pocock 1975). This ideal had roots in ancient political philosophy, was brought back to life in humanism in Florence around 1500, and formed the political background of the reformation in Zurich after 1520. Later, it shaped the founding of the Commonwealth of England (1649-1660) as well as the Puritans, who emigrated to the British colonies in North America, and it was particularly revived in the founding years of the United States. It is a firmly antimonarchist - that is, republican - and anticapitalist political ideal, in which the citizens virtuously stand up for the 
common good. Their only passion is patriotism, love of the fatherland and its laws, which the citizens themselves have issued in self-government.

\section{The Educationalization of the World in the Long Eighteenth Century II: The Solution}

However, the advancement of the commercial society could not be halted by fully developing the ideal of the republican citizen. The natural sciences produced know-how for farming methods in agriculture, and surplus products were exported. Technical advances simplified the production of goods, trade flourished, and the capitalist bourgeoisie pushed for more political influence, especially in France, which ultimately led to the outbreak of the French Revolution in 1789, legitimized by theories of progress. On the other hand, and somewhat paradoxically, over the course of the eighteenth century the political ideal of the anticapitalist citizen committed to the common good became increasingly attractive. The two opposing ideals were the central issue in a large part of the famous debates between the Federalists and the Anti-Federalists concerning the Constitution of the United States.

In other words, in the second half of the eighteenth century, the contradiction between progress in science and the economy on the one hand, and the popularity of the ideal of the anticapitalist citizen on the other, led to attempts to reconcile the two positions. It was not by chance that this reconciliation was pursued effectively in the Protestant strongholds of Switzerland. Protestantism - notwithstanding its different denominations - had turned from the Catholic emphasis on the institution (the Holy Mother Church) to the individual's soul as the instance of salvation, with no fundamental need of consecrated mediators (priests) between God and the individual. This Protestant focus on the individual's soul became the starting point of the educationalization of the world, insofar as the soul became the central object of education. The difference between German Protestantism (Lutheranism) and Swiss Reformed Protestantism (Zwinglianism and Calvinism) led to two different educational ideologies. Whereas Luther's unworldly political and social ideology led to the political indifferent and antimaterialistic contemplative educational ideology of Bildung (Horlacher 2016); the Swiss Reformed Protestantism developed an educational program aimed at active citizenship as a reaction to these fundamental transformations.

The key to accepting the changing living conditions towards a commercial life on the one hand and at the same time to adhering to the republican ideal of the selfless patriotic citizen on the other hand was to focus on the danger zone, so to speak, that is the human soul. Against the background of a commercializing society and the maintained ideal of the virtuous republican citizen, the keyword was "correct modification" of the soul - making the soul virtuous - which was interpreted as strengthening the soul, developing inner strength. This idea subsequently became 
the starting point of the educationalization of the world, for it meant that a person with sufficient inner strength or virtue could safely resist all temptations of the (commercial) world and be a virtuous and active citizen. Here, inner strength represented the Protestant internalization of the steadfast Roman warrior hero, fighting not so much the enemy in the battlefield but rather the inner enemy of selfish passion. It was to be expressed as republican virtue in the time of commercialization; in this way it interlaced the common good and commercial society and thereby shaped the future for the welfare of all.

This modification - that is, strengthening the soul towards (civic) virtue - was the program that was to be realized through education. In this cultural transformation process the "self" became the crucial object of the growing subject; it was constantly assessed and monitored through self-reflection, which was often recorded in diaries. Educating the young towards self-examination thus appeared as the key to resolving the conflict between republican politics and the modern economy, as guarantor of an ordered modernity that does not fall prey to the passions related to power but instead is meant to ensure the common good and progress. Those who - through education - could strengthen the souls of children did not have to fear the open-ended and uncertain future of a commercializing society. It is this idea that is at the origin of the educational turn, the great transformation process that educationalized the world in a lasting way. Many persons had a part in shaping and popularizing this transformation, but none were as influential as Zurich-born Johann Heinrich Pestalozzi (1746-1827), who through his lifetime became the great promoter of an educationalized world, the star of an educationalizing culture that started to assign more and more perceived social problems to education (Tröhler 2013). This was the basis of the erection of mass schooling as the likely most successful new social subsystem in the Western world through the nineteenth and the twentieth centuries.

\section{Educationalization of Social Problems as Phenomenon of the Educationalization of the World}

The overall political, social, and cultural transformations brought about by the American Independence and the French Revolution created manifold uncertainties, in which the educationalization of the world became contextually nourished and demanded educational instruments or methods. Competing methods were propagated: Johann Ignaz von Felbiger's “normal method," Andrew Bell and Joseph Lancaster's monitorial systems, and Pestalozzi's educational method, which promised both harmonious-natural development of all the human faculties and morality and virtues. However, even if the monitorial or the normal method proved, for limited purposes, to be more successful than Pestalozzi's method, it was the latter that became the icon of the educational turn at the turn of the nineteenth century, possibly precisely because his 
method proved to be not really applicable at schools. The reduction of Pestalozzi's education aspiration - forming the virtuous citizen - to modern schooling was never his intention; his aim was more the educational salvation of Europe against the background of its moral and political decay: Good (virtuous) politics depended on a good education, and good education depended on "face to face and heart to heart" encounters.

Even when after a quarter of a century of political and social upheavals and economic transformations between the outbreak of the French Revolution and the Congress of Vienna, the European countries decided upon a program that was called restoration; Europe was on a track of progression, desperately in need of reassuring social order. Ideas of natural laws and the inalienable rights of every man as well as the local/regional identities of most of Europe's inhabitants had to be made compatible with the newly defined territorial entities called the nationstates. Whereas these nation-states were becoming defined and justified politically by the constitutions and defended militarily by the armies, the inner coherence of the nation-state, the inhabitants' identification with the nation-state, had to be made by education, respectively the school systems. The educationalizing culture in the beginning of the nineteenth century expressed the hopes and fears of an unknown future that had to be ensured through loyal citizens, resulting from educational processes to be implemented in organizational contexts, the schools. As a rule, all the nation-states defining themselves constitutionally as territorial entities passed encompassing education acts within 2-3 years after passing their constitutions (Tröhler 2016 in press).

It is one of the characteristics of an educationalized culture to react to unfulfilled expectations not only with educationalization of perceived social problems but also with more and allegedly better educational opportunities in general. Compulsory education was continuously extended and teachers trained more and more. The moral part of this teacher training had to be covered through the genre history of education and the more practical part through psychology of education. The ennoblement of teacher training to an academic subject/field was largely owed to the ongoing establishment of psychology as academic discipline, whereby it is no coincidence that psychology focuses on the individual's soul and that the earliest psychologists were - with hardly any exception - sons of Protestant ministers and/or had studied Protestant theology themselves (Tröhler 2011). But even when psychology had become an autonomous discipline working with empirical methods, the educational rhetoric remained idealistic, serving moral values deemed relevant for individuals to cope with the manifold challenges of progress, resulting from the enhanced knowledge production and knowledge dissemination in the educational systems. Against this background, the educationalization of the world was not limited to solving perceived social problems such as health, crime, economy, ecology, traffic, military, teenage pregnancy, public behavior, or drugs and alcohol but was more fundamentally connected to the process of modernization itself, brought about by the modern sciences and ideas of freedom. Both the 
sciences and freedom seemed to be inevitable and desirable but at the same time under constant suspicion of creating an endangered individual, and it is here that education becomes a fundamental part of the modernist narrative itself and not only of the process of the history of Western education, which would limit its focus to the educationalization of social problems. The educationalization of the world, transnationally propagated by organizations such as the OECD and globally disseminated by organizations like the World Bank or UNESCO, is the key to understanding the cultural (and ultimately Protestant) construction of modernity and the modern self as a self-reflective lifelong learner in the system of thought that embodies fears and the hopes for redemption at the very same time.

\section{Cross-References}

Environment and Education

Nationalism, Curriculum, and the Making of Citizens

$\underline{\text { Religion and Modern Educational Aspirations }}$

The Quest for Heroes

\section{References}

Carson, R. (1962). Silent spring. Greenwich: Fawcett.

Depaepe, M. (2012). Between educationalization and appropriation. Selected writings on the history of modern educational systems. Leuven: Leuven University Press.

Depaepe, M., \& Smeyers, P. (Guest Eds.). (2008). Symposium on the educationalization of social problems. Educational Theory, 58(4), 379-474.

Fischer, A. (1929). Germany. In Educational yearbook of the international institute of Teachers College Columbia University 6, https://www.tcrecord.org/edyearbook/Content.asp?ContentId= $\underline{14761}$

Foucault, M. (1977). Discipline and punish. The birth of the prison. New York: Random House. (French original 1975)

Foucault, M. (1978). History of sexuality. Volume I: An introduction. New York: Pantheon books. (French original 1976) 
Horlacher, R. (2016). The educated subject and the German concept of Bildung. A comparative cultural history. New York: Routledge.

Labaree, D. F. (2008). The winning ways of a losing strategy: Educationalizing social problems. Educational Theory, 58(4), 447-460.

\section{$\underline{\text { CrossRef }}$}

Pocock, J. G. A. (1975). The Machiavellian moment. Florentine political thought and the Atlantic republican tradition. Princeton: Princeton University Press.

Proske, M. (2001). Pädagogik und die Dritte Welt. Eine Fallstudie zur Pädagogisierung sozialer Probleme. Frankfurt am Main: Johann Wolfgang Goethe-Universität.

Rickover, G. H. (1959). Education and freedom. New York: Dutton \& Co.

Smeyers, P., \& Depaepe, M. (Eds.). (2008). Educational research: The educationalization of social problems. Dordrecht: Springer.

Tröhler, D. (2011). The becoming of an educational science: The Protestant souls and psychologies. In D. Tröhler (Ed.), Languages of education: Protestant legacies, national identities, and global aspirations (pp. 131-147). New York: Routledge.

Tröhler, D. (2013). Pestalozzi and the educationalization of the world. New York: Palgrave Pivot. $\underline{\text { CrossRef }}$

Tröhler, D. (2016). Curriculum history or the educational construction of Europe in the long nineteenth century. European Educational Research Journal, 15 (in press); DOI:

$10.1177 / 1474904116645111$ 